小腸再発転移巣からの G-CSF 産生を認めた

原発性肺癌の 1 例

江口圭介 $1,2 \cdot$ 小林紘一 1

要旨——背景. Induction chemotherapy 後の再発において小腸転移巣からの granulocyte-colony stimulating factor (以下 G-CSF) の産生を認めた原発性肺癌の 1 例を報告する. 症例. 55 歳男性. 検診で胸部異常陰影を指摘されて当院 を受診, 手術療法と術前後の化学療法 (CBDCA + CPT-11) を計 3 クール施行した. 術前化学療法は著効し, 切除検体 より large cell carcinoma with mucin と診断された。術後約 5 か月に縦隔リンパ節再発が発見され GEM 単剂による治 療を開始したが，経過中に大量下血と，血清 G-CSF 高值を伴う末梢血白血球（好中球）数の異常増多を認めた. 出血 源である小腸多発転移巣の可及的切除により, 一時的に下血は減少し, 血清 G-CSF 值の低下とともに末梢血好中球数 も減少したが，患者は肺手術後約 10 か月で死亡した。結論. 原発巣には認められなかった G-CSF 産生が, Induction chemotherapy 後の小腸転移再発とともに確認されるようになった本症例の臨床経過は G-CSF 産生肺癌症例の中でも 特異的である.（肺癌. 2002;42:619-623)

索引用語 ——術前化学療法, 肺癌小腸転移, G-CSF 産生腫痬

\title{
Granulocyte-colony Stimulating Factor (G-CSF) Producing \\ Recurrent Tumors of the Small Bowel in a Patient With Lung Cancer
}

\author{
Keisuke Eguchi ${ }^{1,2}$; Koichi Kobayashi ${ }^{1}$
}

ABSTRACT — Background. Leucocytosis arising from a high blood concentration of tumor-produced G-CSF and metastasis to the small bowel are both rare events in patients with lung cancer. We report a case with G-CSF producing metastatic tumors of the small bowel identified after induction chemotherapy for a primary lung cancer. Case. A 55year-old man was with an abnormal shadow on his chest X-ray film was admitted and non-small cell lung cancer was diagnosed. Chemotherapy with carboplatin at AUC 5 (day 1) and CPT-11 $\left(60 \mathrm{mg} / \mathrm{m}^{2} ;\right.$ days 1, 8, 15) was repeated 3 times ( 2 courses before the operation and one course after the operation) every 4 weeks. The primary lesion was almost completely resected by a left upper lobectomy with lymph node dissection. Tumor recurrence in mediastinal lymph nodes was diagnosed 5 months after the operation. Chemotherapy with gemcitabine $\left(800 \mathrm{mg} / \mathrm{m}^{2}\right.$ weekly $)$ was started soon after, but the patient developed leukocytosis $\left(56100 / \mathrm{mm}^{3}\right)$ with a high serum level of G-CSF and massive melena from metastatic tumors of the small bowel. An emergency bowel resection was performed to stop the bleeding, and the peripheral white blood cell count and serum G-CSF level were decreased immediately after surgery. Immunohistochemical staining revealed G-CSF production not in the primary lung cancer tissue, but in the metastatic intestinal tumor tissue. The bleeding also decreased temporarily, but the patient died 10 months after the first operation. Conclusion. G-CSF production mainly occurred in the recurrent tumor of the small bowel after the start of induction chemotherapy for primary lung cancer. At this point, the clinical course is very unique among reported cases of G-CSF producing lung cancers. (JJLC. 2002;42:619-623)

KEY WORDS — Induction chemotherapy, Small bowel metastasis from lung cancer, G-CSF producing tumor

\footnotetext{
1 川崎市立川崎病院呼吸器外科 ; 2 慶應義塾大学医学部外科.

別刷請求先：江口圭介, 慶応義塾大学医学部外科, ₹ $160-8582$ 新宿区信濃町 35 番地 (e-mail: egukei@aol.com).

${ }^{1}$ Department of General Thoracic Surgery, Kawasaki Municipal Hospital, Japan; ${ }^{2}$ Department of Surgery, School of Medicine, Keio University, Japan.

Reprints: Keisuke Eguchi, Department of Surgery, School of Medicine, Keio University, 35 Shinano-machi, Shinjuku-ku, Tokyo 160-8582, Japan (e-mail: egukei@aol.com).

Received July 1, 2002; accepted August 6, 2002.

(C) 2002 The Japan Lung Cancer Society
} 


\section{はじめに}

肺癌において腫瘍細胞からの granulocyte-colony stimulating factor (以下 G-CSF) 産生を伴う症例は通常の肺 癌治療に反応性がそしく予後不良である。肺癌の小腸転 移は消化管出血, 1 穿孔, 2 腸閉塞 3 などを発症し, 緊急 の外科的処置が必要となることがあり注意が必要であ る. 両者はいずれも稀な病態であるが，我々は術前化学 療法後に切除し得た原発性肺癌症例において, 小腸転移 再発巣からの G-CSF 産生を観察した. 腫瘍生物学的観点 からも興味深い症例であり若干の考察を加えて報告す る.

\section{症 例}

症例は 55 歳の男性で, 会社の検診で胸部異常院影を指 摘され当院を受診した．既往歴には特記すべきものはな い. 入院時血液検査所見では, 白血球数は正常 $(8870 /$ $\mu \mathrm{l}$; 好中球 $57.7 \%$, リンパ球 $34.3 \%$ ）で腫瘍マーカー (CEA，SCC，NSE）も正常範囲内であった。胸部単純レ ントゲン写真では左肺門陰影の増大と左中肺野に $3 \mathrm{~cm}$ 径の結節陰影を認め (Figure 1), 胸部 $\mathrm{CT}$ で左上葉 $\mathrm{S}^{3}$ に $3 \mathrm{~cm}$ 径の腫瘤影と左縦隔から肺門にかけてのリンパ節 腫大を認めた (Figure 2A). 気管支鏡生検で非小細胞肺癌 と診断され, 画像診断上, 遠隔転移は認めなかった。 以 上より cT1N2M0, stage IIIA と診断し, CBDCA (AUC 5, 点滴静注第 1 日) と CPT- $11\left(60 \mathrm{mg} / \mathrm{m}^{2}\right.$, 点滴静注第 1 , 8，15日）による化学療法を 2 タール施行した。 2000 年 8 月 31 日の胸部 CT で原発巣は $1.7 \mathrm{~cm}$ 径に縮小し, リン パ節も縮小した（Figure 2B）ため，同年 9 月 6 日左上葉 切除，リンパ節郭清（ND2a）を施行した。切除標本上の 腫瘍の大部分は凝固壊死を呈しており，治療効果は Ef. 2 と判定された。癌細胞は明瞭な核小体を有するやや 大型の異型核と，細胞境界不明瞭ながらやや好酸性を呈 する胞体よりなり，細胞間橋は不明瞭で腺腔構造も顕者 でないため large cell carcinoma with mucin (学会分類) と 診断された(Figure 5A1). 手術所見では $2 \mathrm{~b}$ 群の縦隔りン パ節には腫大を認めなかったため郭清は省略したが，郭 清した $2 \mathrm{a}$ 群縦隔リンパ節にも組織学的にリンパ節転移 はなく，肺内リンパ節の一部に認められた転移巣もすべ て凝固壊死に䧃り viable cancer cell は認められなかった。

術後経過は良好で CBDCA とCPT-11による化学療法 の追加を試みたが，血小板減少の副作用が著しく，続行 困難となり1タールを終了後退院となった。

2001 年 1 月 29 日の CT で頸部〜縦隔のリンパ節腫大 を認めたため, 再発と判断して GEM $800 \mathrm{mg} / \mathrm{m}^{2}$ 単剂, 隔 週投与による外来治療を開始した。 2 か月後の胸部 CT ではリンパ節の縮小を認めたが，化学療法中に下血によ る貧血が顕性化した。同年 4 月 23 日の血液検查で $\mathrm{Hb}$

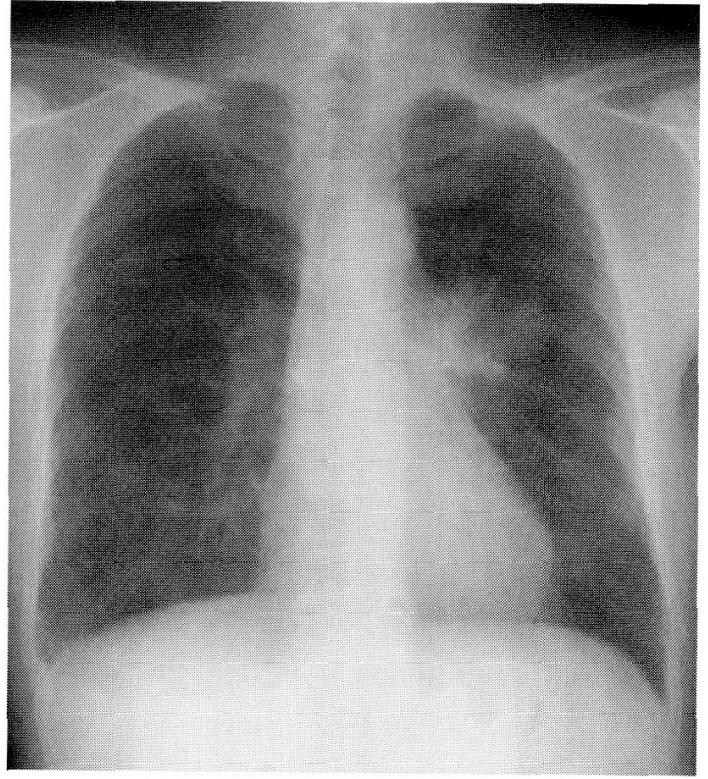

Figure 1. Chest X-ray film taken on admission.

$4.7 \mathrm{~g} / \mathrm{dl}$ の低下と同時に末梢白血球数の増多 $(56100 / \mu \mathrm{l}$, 分葉核球 $85 \%$ ）認めた．腹部 CT, 消化管内視鏡等の検 查で, 出血源となる小腸転移が Vater 乳頭部近傍から回 腸末端までの間に多数散在していることが確認された。 画像診断上, 脳, 肝臓, 副腎および骨には転移を認めな かった．小腸転移の完全な切除は困難であったが，連日 輸血が必要な状態が続いたため, 患者の同意の上に 2001 年 5 月 16 日, 出血の軽減のための開腹手術を施行した。

手術では小腸を Treitz 勒带より肚門側で大小の腫瘍 の集中する部分で 3 か所, 合計約 $1 \mathrm{~m}$ 切除した。 小腸管 腔をほぼ閉塞する大径の腫瘍を原因として腸重積を生じ ている部分も認められた．切除標本では多発した 1.5〜 5 $\mathrm{cm}$ 径の一部潰瘍周庭を伴う隆起病変を認めた（Figure 3). 病理診断では, 腫瘍は核小体の明瞭な大型異型核と 微細顆粒状の包体を有する大型細胞が所々で変性し, 好 中球浸潤を伴って增殖する未分化大細胞癌で, リンパ管 および静脈侵襲も明らかであり肺癌原発巣からの転移に 矛盾しないと診断された (Figure 5B1). 小腸切除後, 末 悄白血球数は減少し, 血清 G-CSF 值は術前 $970 \mathrm{pg} / \mathrm{ml}$ に対して術後 $305 \mathrm{pg} / \mathrm{ml}$ と減少を示した (Figure 4).また 抗 G-CSF モノクローナル抗体による免疫染色では, 肺の 原発巣は（化学療法前の生検材料および切除検体）陰性 であるのに対して小腸転移巣は陽性を示した（Figure 5 $\mathrm{A} 2, \mathrm{~B} 2)$. 手術後, 下血は減少し, 一時は外泊も可能となっ たが, 徐々に全身状態は悪化して 2001 年 7 月 2 日に死亡 した，解剖は許可されなかった。

\section{考 察}

肺癌の小腸転移と G-CSF 産生腫瘍は, 組織型ではいず 
A
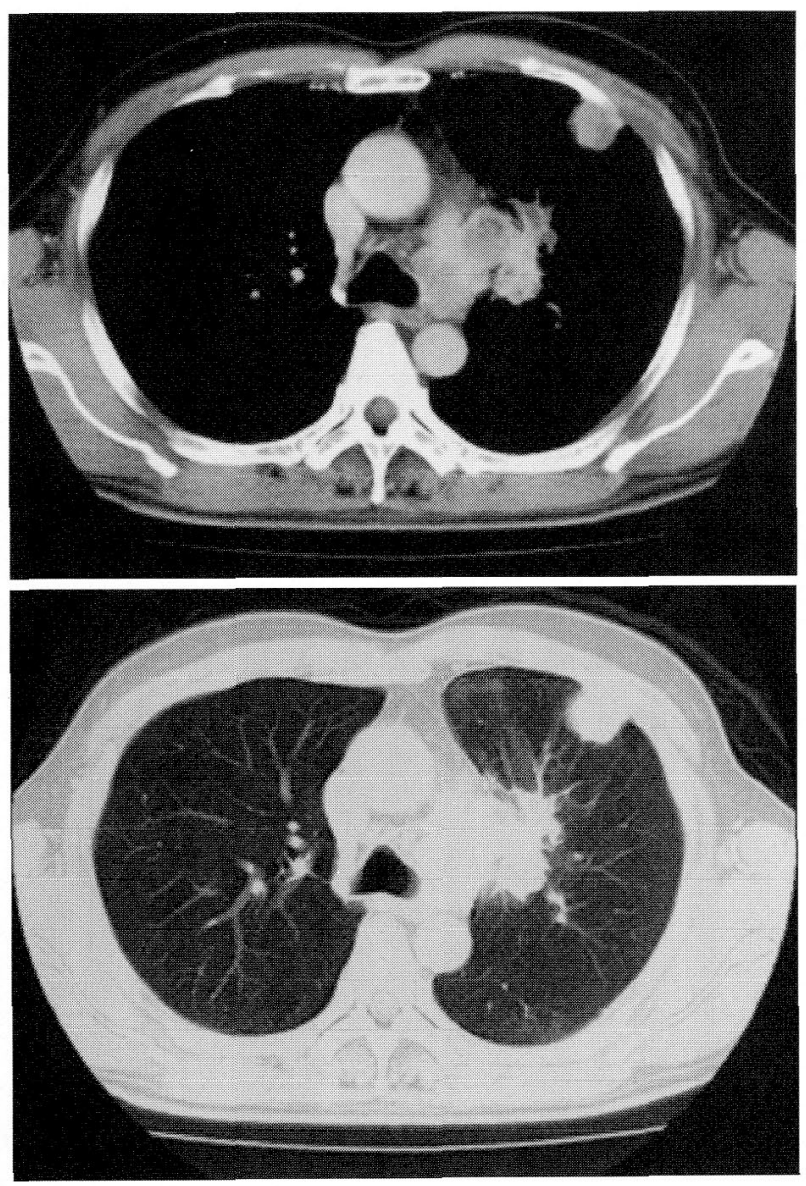

B
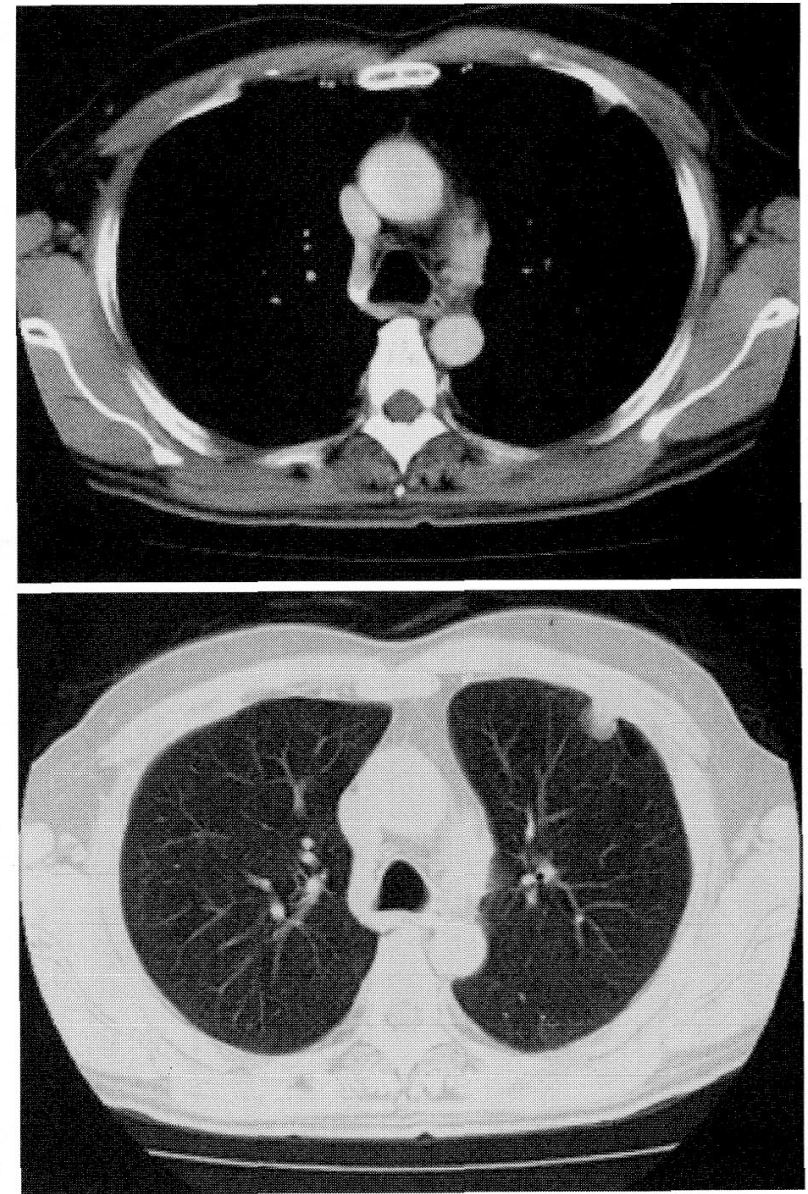

Figure 2. A. Chest CT scan taken on admission shows a tumor in the left upper lobe and mediastinal lymph node swelling. B. Chest CT scan taken after chemotherapy shows a reduction in the size of the tumor and the lymph node.

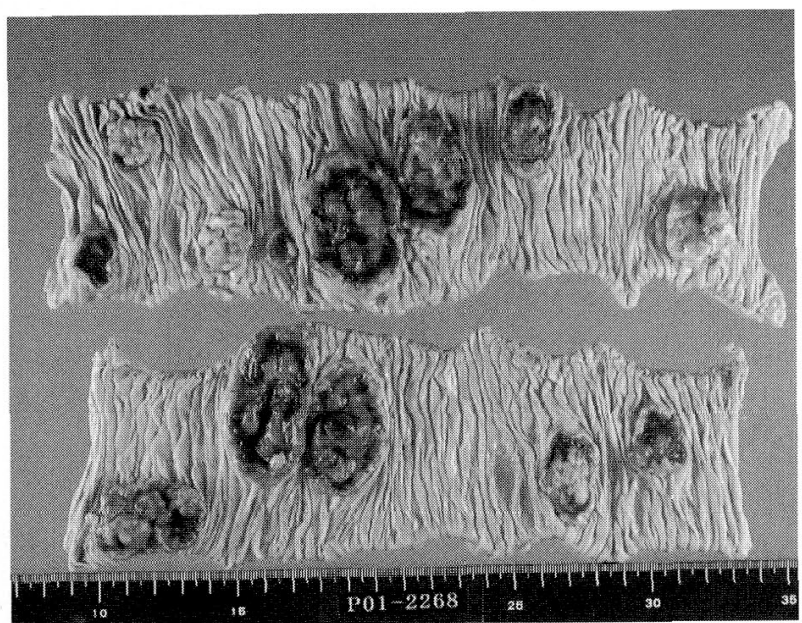

Figure 3. Specimen of the resected small bowel shows multiple metastatic tumors.
れも大細胞癌ないし低分化癌の報告が多く見受けられ る.4,5自験例も切除標本から large cell carcinoma with mucin の診断を得た。 小腸転移は剖検例では原発性肺癌 の $2.3 \sim 4.5 \%$ に認められるとされているが, 6,7 臨床上発 見されるのは有症状の症例にほぼ限られるためさらに稀 となる. 本症例では原発巣の治療後, 約 7 か月で下血に より小腸の転移巣が確認された. 中川らは肺癌原発巣切 除後に小腸転移を手術した 5 例の肺手術と腹部手術との 間は平均 6.6 か月であったと報告しているが, 8 一方 IB 期と診断された肺癌の手術後 10 日で小腸転移が発見さ れた症例も報告されている.9これらの報告は, 無症状の 小腸転移の診断が困難であることも一因であるが，小腸 転移が臨床上の比較的早い段階に起こる可能性が高いと いうことを示唆している。 小腸転移の早期発見が予後の 改善にどの程度寄与するかは不明であるが，もし簡単な 診断法が開発されれば，緊急妈置を必要とする状況は回 避できるようになる可能性はある。

再発時まで白血球（好中球）増多が確認されなかった 
G-CSF Production in Metastatic Small Bowel Tumor-Eguchi et al

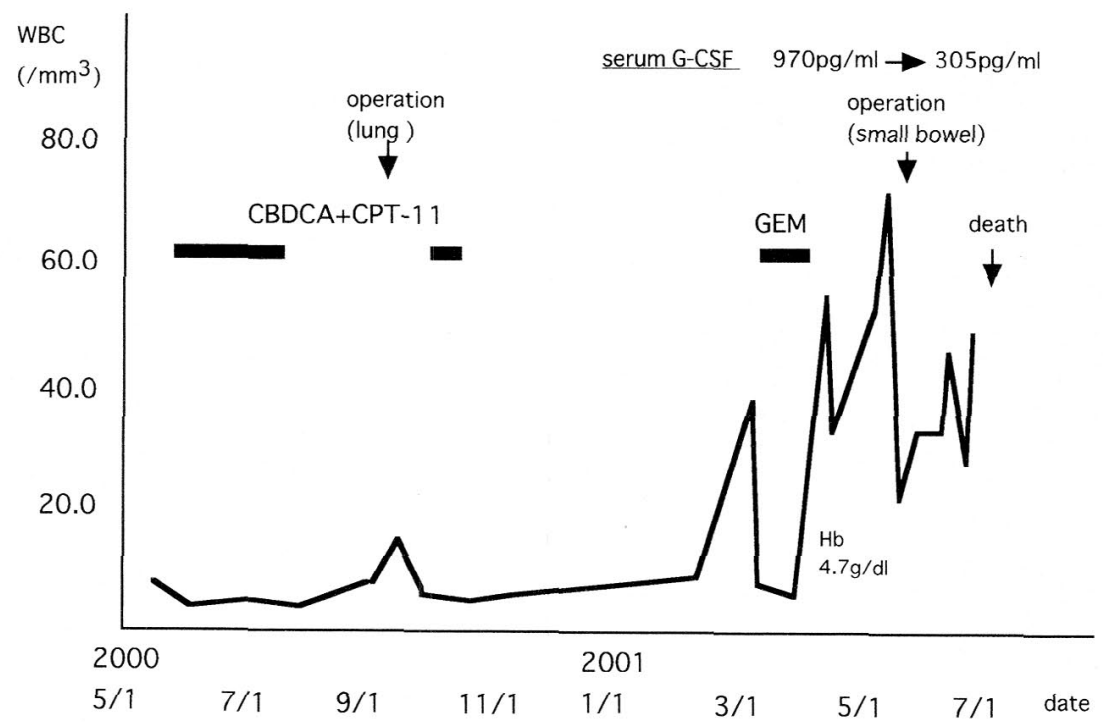

Figure 4. Clinical course.

A
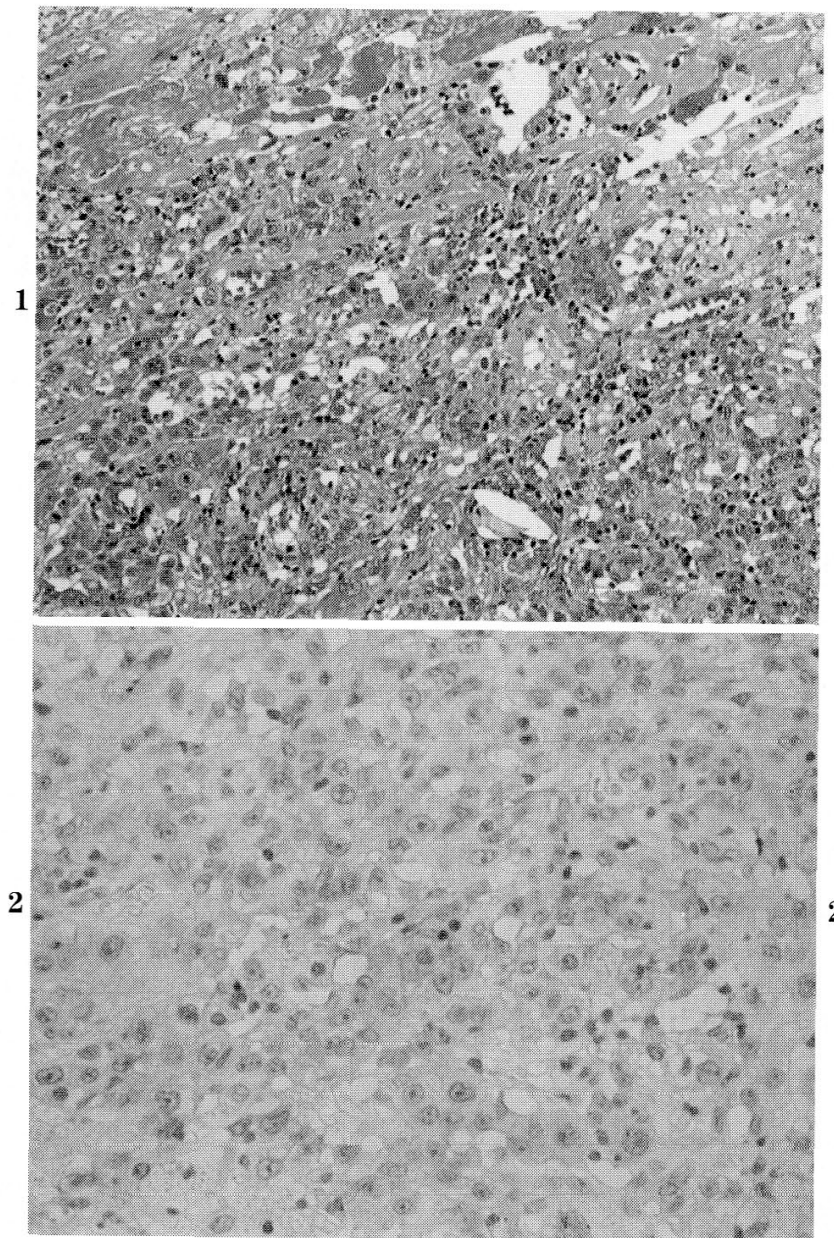

B
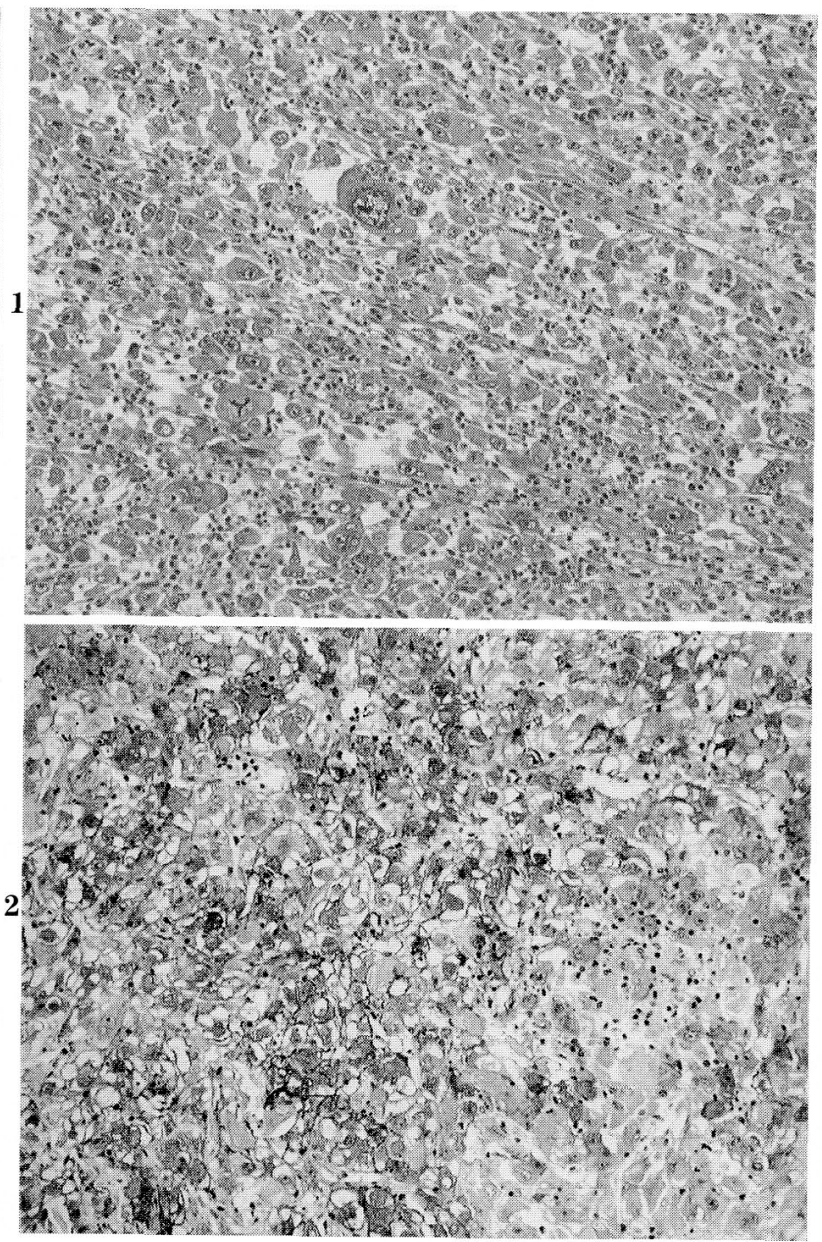

Figure 5. A1. Histological findings of the primary lung tumor. A2. The immunohistochemical findings of the resected tumor are negative for G-CSF. B1. Histological findings of the metastatic tumor of the small bowel. B2. The immunohistochemical findings of the tumor are positive for G-CSF. 
こと, 高值を示した血清 G-CSF 值が小腸切除後に低下し たこと, G-CSF 免疫染色で原発腫瘍は陰性であるのに対 して小腸転移腫瘍は陽性であったことの 3 点から, 化学 療法の著効した原発肺癌の大部分の細胞には有意な G$\mathrm{CSF}$ 産生能はなく, 化学療法抵抗性で高転移能の G-CSF 産生癌細胞が小腸に多数の転移巣を形成したという仮説 が成り立つ. G-CSF 産生肺癌は進行癌として発見される ことが多く, Induction chemotherapyを施行した症例も 報告10されているが, 一般には治療抵抗性で予後不良で ある.もし本症例のように化学療法感受性の異なる細胞 が混在している G-CSF 産生腫瘍であれば, 化学療法で一 時的に腫瘍縮小効果が得られても, 早期の再発の可能性 は高くなるであろう. 深田らは, 胃転移と同時に発見さ れた G-CSF 産生肺大細胞癌において, 抗 G-CSF モノク ローナル抗体による免疫染色の結果が肺原発巣で陰性 で, 胃転移巣で陽性であったことを示し,11 その原因を G-CSF の細胞内貯留時間の短さから染色されなかった のではないかと考察しているが, 12 自験例で主病巣が陰 性であったことは実際に産生がなかったと判断してもそ の他の所見と矛盾しない. G-CSF 産生肺癌は進行癌で発 見されることが多いが, 本症例も小腸転移症状で初めて 発見されていれば，このような臨床経過は観察できな かったであろう。

縦隔リンパ節再発の時点でも白血球数増多を認めてい たが, 化学療法による白血球数減少にマスクされ異常の 認識が遅れてしまった。 また下血による貧血も当初, 化 学療法の副作用との区別がつかなかった. G-CSF 産生肺 癌では化学療法が適応となる可能性が高いので, このよ うな点にも注意が必要である。

本症例の病態は複雑であり, 治療方針についても議論 の余地はあるかもしれない. 副作用等の問題があったも のの化学療法が徹底されていない点は反省すべき点であ る. しかし化学療法に抵抗性の癌細胞が再発の主体と なったとすれば, 同じ薬剤による治療を繰り返しても効 果は期待できない. リンパ節郭清範囲が不十分であるこ とを指摘する意見もあるかもしれない. 本症例では術後 化学療法と放射線療法の追加を予定し広範囲な郭清は施 行しなかったが, 急速な経過のため, 放射線治療を導入
するまで至らなかった. 小腸転移に関しても自験例は広 範かつ多発であり完全な切除はできず，積極的治療が可 能な状態となるまでの効果は得られなかった。しかし現 状の小腸転移に対しては外科治療が最も有力であり, 単 発例では若干の予後延長も期待できる.8それには十分 な臨床的観察で時期を逸さないことと積極的に開腹手術 を施行することが必要であろう。

謝辞：稿を終えるに当たり, 本症例の病理組織学的診断に御 協力いただいた当院中央検査科病理部長杉浦仁先生に深く感 謝の意を表します.

\section{REFERENCES}

1. 中坪直樹, 山口博紀, 佐藤宗勝, 他. 下血を呈した小腸転移 の 1 例. 日本臨床外科学会雑誌. 1997;58:2904-2908.

2. 成清道博, 朴 秀一, 中谷勝紀, 他. 穿孔性腹膜炎で発症 した肺癌小腸転移の 1 例. 日本腹部救急医学会雑誌. 1997;17:1081-1085.

3. 山田 忍, 藤本泰久, 高島 勉, 他. 腸閉塞をきたした肺 癌小腸転移の 1 例. 日本腹部救急医学会雑誌. 1999;19: 373-377.

4. 春日郁馬, 市瀬裕一, 米丸 亮, 他. 白血球増多を伴った 肺癌症例に扔ける血清コロニー刺激因子 (G-CSF) 及び GCSF 産生に関する検討. 肺癌. 1997;37:61-66.

5. 高田一郎, 颂川芳彦, 田畑雅弘, 他. 小腸転移を認めた肺 大細胞癌の 2 例. 肺癌. 2001;41:783-784.

6. 上原克昌, 飯島耕作, 長谷川紳治, 他. 肺癌の消化管転移一 肺癌剖検例 1775 例の検討一. 外科. 1979;41:1364-1367.

7. Antler AS, Ough Y, Pitchumoni CS, et al. Gastrointestinal metastases from malignant tumors of the lung. Cancer. 1982;49:170-172.

8. 中川勝裕, 安光 勉, 古武彌宏, 他. 肺癌小腸転移手術例一 自験例 7 例と本邦 126 例一. 肺癌. 1996;36:319-324.

9. 四方裕夫, 上田善道, 土島秀次, 他. 肺癌術後に小腸転移 で気付かれた肺癌小腸転移症例の経験. 日本呼吸器外科 学会誌. 2001;15:613-617.

10. 松本春信, 古川 浩, 岡原仁志, 他. Induction therapy により切除し得た G-CSF 産生肺癌の一例. 山梨肺癌研究 会会誌. 2000;13:14-19.

11. 深田民人，吹野俊介，林 英一，他．胃転移を伴った GCSF 産生肺大細胞癌の一例．胸部外科．2000;53:798-803.

12. 西垣 豊, 大崎能伸, 山口修二, 他. 免疫染色に局在を示 し得た G-CSF 産生肺腺癌の一例. 日本胸部臨床. 1998;57: 714-719. 